UCRL--94217

DE87 003394

\title{
CONSTRUCTION AND OPERATION OF THE 12-T SUPERCONDUCTING COILS FOR THE MIRROR FUSION TEST FACILITY
}

J.P. Zbasnik, T.A. Kozman, D.w. Shimer and D.R. Hathaway

This paper was prepared for submittal to the

1986 Applied Superconductivity Conference Baltimore, Maryland

September 28 - October 3, 1986

September 25,1986

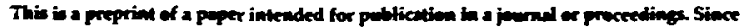

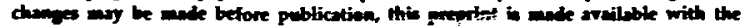

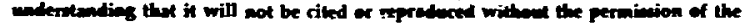
ancher. 


\section{DHSCT_AISIE}

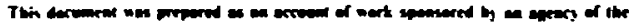

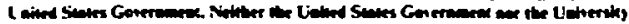

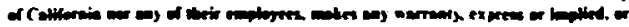

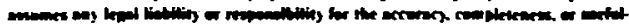

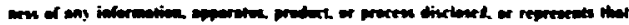

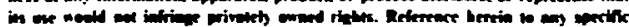

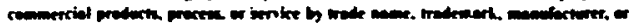

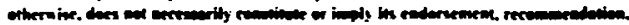

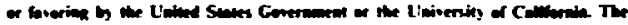

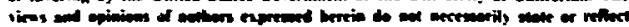

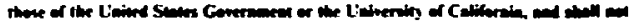

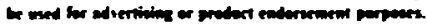




\section{Abstract}

We have successfully congtructed and tested a palr of high-field colis that is part of the pasnet set of the Mirror Fusion Test Facllity (MfTF-3) at the Lawrence Livertore Natfonal Laboratory. Each coll conslats of a multifllamentary $\mathrm{Nb}_{3} \mathrm{Sn}$ megnet nested inside a multiflamentary NbTi magnet. During our test, these colls produced a central fleld of $12 \mathrm{~T}$, with a peak conductor field of $12.5 \mathrm{~T}$. The dimensions of the $\mathrm{Nb}_{3} \mathrm{Sn}$ insert coll are: 1.34-m bore, 2.57-m outer diameter, and $1.14-m$ overall length. These coils were degigned to be fully oryogenieally stabilized and cooied by pool-bolling liquid helium. The operating current density of the $\mathrm{Nb}_{3} \mathrm{Sn} c 011 \mathrm{~s}$ is $2000 \mathrm{~A} / \mathrm{cm}^{2}$ and $2400 \mathrm{~A} / \mathrm{cm}^{2}$ for the NoT 1 magnet. In this paper. We present design considerations and details, construetion $t \rightarrow c h n i q u e s$, and operational results of these colls.

\section{Introduction}

The Mirror Fusion Test Faciliey (METF-B). comissioned in February 1936, at the Laurence Livermore National Laboratory (LiNL), songlsts of 42 superconductlng aagnets that were cenflgured for plastia fhysics experlatents on zandem wirror fugion machlnes. 1 The colls, whlch weigh slightly over 1000 tonnes, are housed in a 59-a lon $\vec{a}$ vacutir vessel, which ras a volume of $-4000 \mathrm{~m}^{3}$. The design reatures and operational details of the vverall facility are presented elsewhere in these proceedings ${ }^{2}$; this paper concentrates on the high-rleld axleell coils. Each of these colls zonsists of an outer NOTi coil, which generates a 6-T Pield on the machine axis, and an insert coil or multifllawentary $\mathrm{Nb}_{3} \mathrm{Sn}$, which boost3 the on-axis fleld to $12 \mathrm{~T}$.

The relevant coil parameters for these colls are listed in Table 1.

\section{Coil Desizh}

\section{High-Field Insert Col I}

A cross section of the nigh-field insert coil is shown in Fig. 1. The conductor, a monolithic $\mathrm{Nb}_{3} \mathrm{Sn}$ composite soldered into a two-piece housing of hardened copper, was yound pancake-style with all the joints on the outer radius. Details of the conductor" and its 四anufacture by the Furukawa Electric Co, were described at an earlier Applied Superconcuctivity Conference. ${ }^{3}$

The coil was operated with the bore orlented norlzontaliy. The turn and parcake insulacion pieces, fabrlcated fros G-10 Ch laminate, are siown if Flg. 2. The flat side of the strlp covers 551 of the conductor surface, while the Brooved side covers $25 \%$. According to the conauctor-pack stress calculations perforped for us by General Dynamics-Convair (GDC) using tha computer program called STANSOL, " the rajial pressure was negligible, so there should be no conductor coining. The pancake insulation, also fabricated from G-10 CR laminate, is slotted, and the pieces are arranged so that the slots tend to channel the halium bubbles,

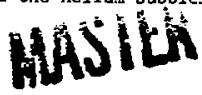

Table 1. Hibn Fiedd Axlcell Parameters.

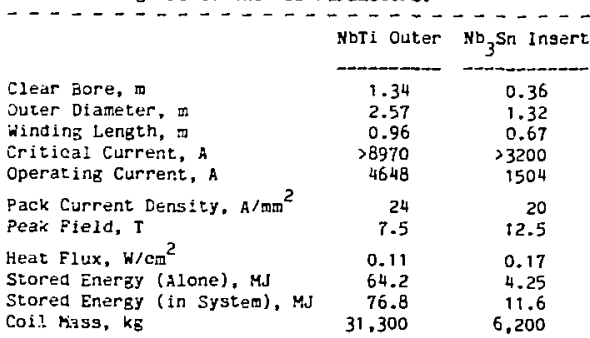

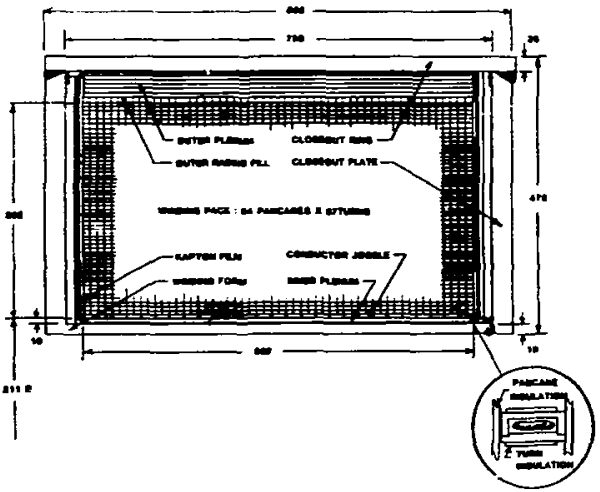

Figure 1. Cross section of the insert coll. Dimensions are in millimeters.

primarily caused by nuclear heating, eway from the high-rield region around the bore tube. The slots allow 435 of the pancake to be exposed to the 11 quid helium. The maximus axial stress on the conductor at the midplane of the wlnaing pack was calculated to be $25.6 \mathrm{MPa}$. At this stress level, the conductor coining was negligible.

The ground plane insulation consigts of 6 layers of 0.13-min-thick polyimide fila (Kapton strips), with a 503 overlap, unich maintains a minimum creepage path distance to ground of $75 \mathrm{~mm}$. The Kapton is protected from danage by $\mathrm{G}-10 \mathrm{CR}$ sheets. The G-10 CR side plates, whlch are positioned between the windings and the Kapton strips, are $7.9 \mathrm{~mm}$ thlck and have $6.4-\mathrm{mm}$ deep grooves, spaced $6.4 \mathrm{~mm}$ apart. The grooves are oriented in the same rashion as the slots in the pancake insulation pleces.

The plenum around the inner bore consists of a grid-Iike pattern that was machined from $\mathrm{G}-10 \mathrm{CR}$ 

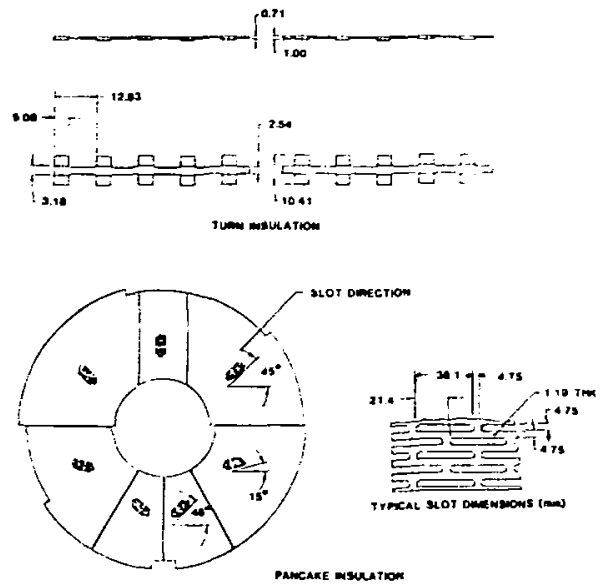

Flgure 2. Turn and pancake 1nsulation. Dimenslons are in milliweters.

laninate. The plenum has a void fraction of approximately $64 \%$, or a total vold volume of approximately 5.6 l. The outer plenum was formed from sheets of G-10 CR, wh1ch were slotted in a manner sigllar to the pancake Insulation pleces. The slots are orlented at approximately $45^{\circ}$ to the horizontal axis, with the slots of alternate palrs of sheets at $90^{\circ}$ to each other, forming a fully permeable structure.

Because of the strain-sensitivity of the $\mathrm{Nb}_{3} \mathrm{Sn}$

superconductor. ${ }^{5}$ control of stregses and stralns in this coll was of great concern. Analysis of tine conductor stress from the combined action of winding tension, cooldown, and Lorentz forces was perforned by GDC with STANSOL. The input to STANSOL 1acluted the winding bobvin, the inner plenum, and 57 conductorinsulation layers. The conductor pack was intended to be self-supporting, so the outer $r$ ing was ignored in these calculationg. A radial podulus of $2.07 \mathrm{GPa}$ was assumed, based on tests of the radial stiffnesses of other MFTF-B colls. An effective hoop modulus was used, which took into account the initial strain state and the stress-strain behavior of the copper houging. The STAKSOL calculations for a 1350-N winding tension yielded a hoop stress that ranged from $75.8 \mathrm{MPa}$ for the first turn to $96.5 \mathrm{MPa}$ at the outer radlus for normal operating conditions. For abnormal conditlons, in which the current was assumed to peak to $115 \%$ of 1 ts normal value, the hoop stress on the first turn was approximately $100 \mathrm{MPa}$. This was well within the capability of the conductor, which has a yleld strength of $207 \mathrm{MPa}$ at $4.2 \mathrm{~K}$.

Bending strains from winding were also thoroughly analyzed by GDC. The conductor was reacted on three concentric spools with diameters of 600,700 , and 800 in in order to maximize productivity. The maximum bending strain from straightening ranged from 0.244 for the 800-an-diameter spool to 0.328 for the $600-m_{-1}$ diameter spool. The bending strain from winding onto the 422-an-dlameter tore was 0.45\%, which was in opposition to the stralghtening strains. The conductor joggle caused an additional $0.04 \%$ bending strain. The mogt severe cumulative iending straln was $0.25 \%$ for the conductor reacted on t'je 800-sm-dlameter spool.

The STANSOL calculations ylelded a maximum hoop atrain of $0.14 \%$ for the abnormal condltion of $1730 \mathrm{~A}$. The total tis $x$.cs.m operating strain of $0.39 \$$ afforded a considerable argin of safety because tests showed that the irreverstble danage onset occurred at $0.8 \%$ strain. ${ }^{3}$

The gtresses in the 30 Lik stainless steel coll case were also analyzed by GUC, ror which they used the 2-D computer program called solidSP. ${ }^{6}$ The coll case was laaded by axial forces lmposed by the other colls in the MFTF-a set. In nornal operation, the insert coil is subjected to a $4710-\mathrm{N}$ axial force, directed away from the machine center, which resulted in a jending stress that peaked at $275 \mathrm{MPa}$ in the closeour weld at the inner bore. Since this was a bending stress, the allowable stress level was $90 \%$ of yleld, or $620 \mathrm{MPa}$, which resulted in a generous margin of safety. Fracture mechanles prirclples were uged to deterolne that a glnimum initlal rlaw glze of 5 mollil ensure fracture-free speration for 4-11fetioe operation, each lifetire conslsting of 490 normal cycles and 10 abnormal cycles. A defect of this size is readily detected by ultrasonic test nethods developed for MFTF-g. Furtier detalls of the deslgn have been shown by Bald 1 , et al. 7

\section{NbT1 Outer Coll}

The NoTI outer colls presented a significant design challenge because constraints of coll size, rleld, cost, and schedule resulted In conductor hoop stralns of 0.0032 for normal operation and 0.0051 for abnoral operation. The stress and strain calculations were done by GDC. who modifled STANSOL to take Into account the sonductor's plastic behavior. Hinding tension and outer case thickness were relatively ineffective in reducing the stress levels, and adding distributed stainless steel reinforcevents resulted in a conductor pack that was too large. Manufacturing a new conductor would have caused an unacceptable schedule slippage.

A comprehensive testing program was undertaken, in wich static and cyclic eechanical testing demonstrated that the NBII corsuctor would survive 4 lifetimes or operation, each consisting of 490 normal cycles and 10 abnormal cycles in wich the current peaked to 1158 of the normal value. Simulated splice joints survived cyclical loading of tension and compression, corresponding to elght lifetimcs or operation.

\section{Fabrication Detatis}

The coll-winding methods and equipment were adapted fron our prevlous work on winding the $\mathrm{Ko}_{3} \mathrm{Sn}$

colls for the LLNL High-Field Test Facllity. ${ }^{8}$ Because the coll was wound pancake-rashion, with joints only on the outer radius, each spool frow the furukawa Electric Co. contalned 295 a of conductor, enough to wind 2 pancakes.

The first step was to transfer half of the conductor fron the shipping spool to the tensioned payorf spool. We found that the midpoint of every length was marked according to our specification, which we verifled with a cillibrated roller. The conductor was unspooled wille under a $450-N$ tension.

After the transfer was completed, the shipping spool was then rastened to the swing are assenbly, which was cantilevered from the center of the winding 
table; the spool orbited as the winder rotated. The sting arm was equipped with dechanisas to conirol the elevation and tilt of the shipping spool, so that the shipping spoo! would cleis the conductor being wound off the payorf spool.

The conductor jogsle and riser plecer, which were rabricated from G-10 Ga laminate, iere bonded into position with Loctite $4: 4$, a syanoacrylate adtesive. The adhesive was used to nold the iters in plase sniy during rabrication; in operaclon, the ploses are held in place by the concuctors.

The first-turn jozbie was rate by a series of operations in which the condwotor was fi:st diexped racially agains: the bore cube and then fresset $3 \times 1$ sil; against the joggle piece by a series of axia: surex clamps, while the axial clampino force wes eprzies, the payorf spool was loiered to prevent ary loealized damage to the conductor. Juring this proceclire, the condictor has under 675-: Eension. No overbenting ias done.

After the jogktz ias formed, the tens $10 n$ was tncreased to $1350 \mathrm{~N}$ and the 5 ? turns in the lower lodsnutoered) pancake jere applied. The ensioner consisted of a basket filled with 300 lo of lead orieks that pulled an the frameirork to which the payosf spoo: was attached. The frase Has tounted on llnear bearings, which allowed a "back and forth" rotion. The required anount of drag to aaintain the fratework's position was proviced by a aechantcal cisc brake ard eiectric brate xotor. which were connected to the payoff spool sinat:

The turn insulation was supplied on reels, which peraitted us to autosatically feed the Insulation ijto the winding. Axlal ciaxps and cusinioned hargter blcirs were used to ensure a szooth pancake wind. Figure 3 shows the coil being wunc.

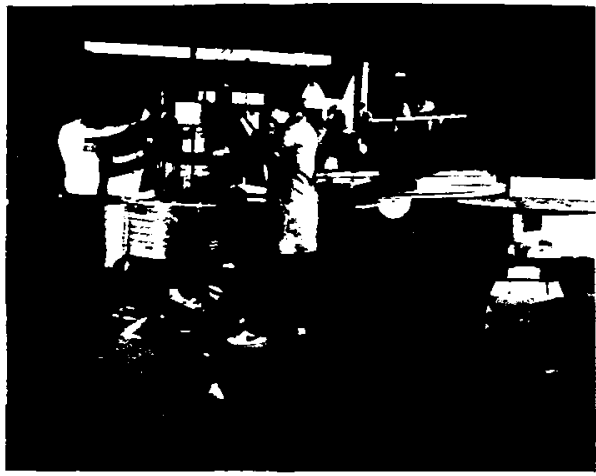

Figure 3. Winding the $\mathrm{Nb}_{3} \mathrm{Sn}$ coll for MFTF-B.

After this lower pancake was completed, radial clamps were used to hold the Hindings, and the conductor was cut at the appropriate location. The shippine spool, which had been orbiting the winder, was then installed on the tensioner, and the conductor it contained was used to wind the next pancake. After the required number of turns were wound, additional radial clamps on the outside of the coil were used to hold the conductor in place. irter each pancare was wound, conductor resistance mezsurements, high-potential wiknstand, and megohm resistance neasurements between pancakes were made to ensure elect.ical integrity, $A \times i a l$ and radlal dinensions were recorded to ansure that the coil was not exhibiting excessive bulldup.

Considerable scatter wes obtained in the individual diknglons, but average values taken over Severa: pancaies indicated that the axial bulldup was quite niniazl, arounting to less than $.02 \mathrm{~mm}$ per paricare.

Figure if stows wo of the steps in aaking the 5ji:ee joint. Each splice consists of three parts: a copper clamp to which the two conductors are soldered with oo/ steel recinanical clctips. Eased on test results, eitner the stainiess steel clanps or the soldered copper clapp is surficient to react the 9.5-kli tensile loed on the concustor with a generous aarsin of safety. The jolnt rEsistance is on the order of $3 \times 10^{-8} \Omega$. Sigure $4 a$ shows the concuctors pulled into position in the bases of the various claxp pleces. A tension of $1359 \mathrm{~N}$ was uses. The blacic oxide coating was recoved from the conductors with fine-grit abrasive paper, and the conduetors dere tinned with 50/40 Sn/Pb solder. Snall clamps were used to prevent the conductor from deleginating during tianing.

The ventilated filier insulation pieces behind the ciaxps were tallor-made for eash pancake, so the splice block would make a wiform contact situltaneously on all four paricantes. Gecause the splices all stacked up on each other, danage to the lower splices was prevented by Inserting between the splices $z$ temporary spacer of leached sllica material with an overlayer of Kapton film. Figure $4 \mathrm{~b}$ shows the assembled claxps in place with the flat-head screws torqued to the proper value. Both eopper pleces were tinned and fluxed prfor to assembly. Heat was applied with the 750-N flatbar-type heater clamped to the front face. Two thermocouples were inserted into the copper piece, one dedicated to the power controller and the

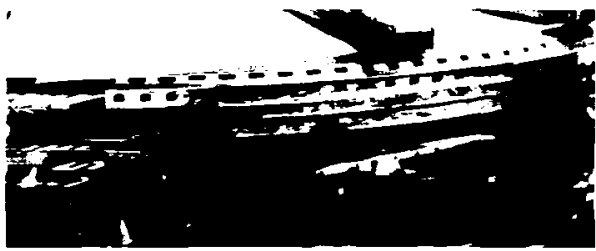

Figure 4a. Conductors are tinned and pulled into position with a 1350-N tension.

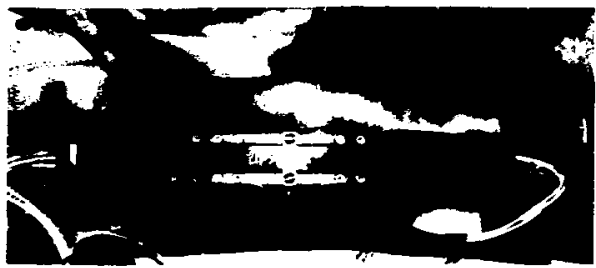

Figure 4b. Space joint ready for neating. 
other to give us a real-time readout of the cemperature. The jolnt area was covered with several layers of leached-sillca, heat-res lstant blanket to prevent heat loss. Ahen the caxperature reached $190^{\circ} \mathrm{C}$, addiclonal solder was $r \equiv d$ througn the gap in the top of the splice blocks. The screds were then retorqued, the heater was shut of $f$ and removed, ant a water-cooled chill bar was attached in its place. The scratis rere again tightened to their proper torque arter the splice had cooled to room temperature. The joint was cleaned and then ultrasonisaliy Inspected. Ne met our criterion to bond bot of the area.

Aftar ali the pancakes were wound, roltage taps were installed on pancaies $t 4,24,26,28$, and 40 , using one of the serews in the approprlate splice foint. Voltage taps at each end of the coll were screwed to the conductor terminals. Additional taps were Installed on fancakes $6,7,46$, and 47 , so that the voltage across the upper one-eigith turn of each of these pancakes could be used to detsot a nornal zone that would be caused by a low-helium level. Such a normal zone mizht not be able to be detected by the quench detector, because if all the pancakes had a sitallar-glzed norral zone, the signals wouid be cancelied oud in the balance circuitry.

The outer radius flller pleces were installed to clrcularlze the coil, and the outer plenum pleces were molded to the proper contour and then installed. The outer layers of Kapton ground-plane insulation were applied, and the 304LN stainless steel closeout plate was elamped in position. Gaps between the closeout plate and the coll pack were filled by a combination of G-10 CR laxinate st-ip and wica-fllled epoxy to ensure unifort contact across the entre plate.

Flgure 5 shous our techniclans installing the outer ring section that contains the tube for tine current leads. The coll was protected from the heat of

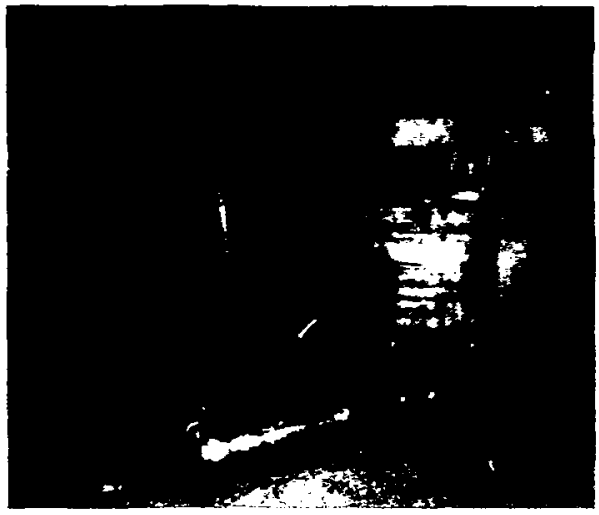

FIgure 5. Installing the outer ring assenbly.

welding by several layers of heat-resistant sllica tape placed behind the weld-joint areas. Root passes in the more sensit1ve areas were made using gas tungsten are welding with Ea316L electrodes that were upecially approved for MFTF-尹 service. The other areas were done with shielded metal-arc welding (SMAH) with approved E316L-15 electrodes. The root passes were checked with dye penetrant to ensure that they wre crack-free. The cover paszes were done with SHAW with approved electrodes. The completed welds were examitied with ultrasontc techniques to ensure that there were no flaws large enough to present fracture problem.

The colls were then given the final electrical crecks to verify that the closeout welding did not cause any problems. Last, every weld area was leak checked to ensure helium leak-tigntness. In order to do this, a novel approach was dereloped in which the coil was pressurlzed with hellum and the weld jolnts were "sniffed" using Corm-fitulng boots that were connected direaty to the leak detector.

\section{Installation and Testing}

The $\mathrm{Nb}_{3} \mathrm{Sn}$ coil was then installed in the NoT1 outer coll. The colis were alizned so that the bore of the two coils were concentric and the midplanes of their winding packs coincided. Twelve 304L shims placed between the outer ring of the $\mathrm{Nb}_{3} \mathrm{Sn}$ coil and the bore of the outer coll were used to malntain radial positioning. The main attachment between these colls was via a three-plece ring that was welded in place.

The high-rield coll assembly was suspended from the vacuum vessel with a palr of $304 \mathrm{LN}$ turnbuckles and from nelghboring colls At and Tl with 304LN links. The four links to $\mathrm{Tt}$ are $34.3 \mathrm{~cm}$ wide and $8.6 \mathrm{~cm}$. thick, $\therefore$.d the I1nks to Al are bone-shaped, with a minimua cross section of 16.5 by $8.6 \mathrm{~cm}$. These were fitted with a spherlcal bearing at each end, located so that colls will be in alignment during operation. The links were pinned with $11.4-c 0$ daweter pIns to clevises welded to the colls. Four turnbuckles connect the A2 coll assembly to 56 , from which struts extend to reinforced clevises on the vacuum chamber and react the axial forces on this group of cotls.

After Installing the liquid hellum pipes. remalning LN, panels, and vapor-cooled current leads, the final leak checks were performed and cooldown was started. A description of the detalls of the liquid helium flow can be found elsewhere in these proceedings. 9

The magnet testing proceeded in a planned series of activitjes during whlch the colls were firgt hipotted. Each cofl was then energlzed to a low level with all other nagnets open circuited and slowly discharged using the power cables as a discharge resistor. For these tests, the $\mathrm{Nb}_{3} \mathrm{Sn}$ coils were energized to $200, A$ and the outer colls to $500 \mathrm{~A}$. During the current's decay, the quench-detector selfinductance bridges were balanced, and wutual inductance data were collected for use in the compensated quench detector. Following this calibration, the axicelis as a Broup (A1. A2O, and A2i) were energized to $50 \%$ of the operating current and then to toof operating current. For the axicell colls, the operating currents were: 960 for A1, 1504 A for A21, and 4648 A for A2o. The magnets were fast dumped from each of these levels to verify proper operation of the dump resistors and circuit breakers. No quenches occurred durIng these tests. The only problems dere erratic power-supply voltages and blown translent voltage suppressors (HOVs) across the $\mathrm{Nb}_{3} \mathrm{Sn}$ colls because their voltage ratings were too low. The peak discharge voltage for the $\mathrm{Nb}_{3} \mathrm{Sn}$ colls was $750 \mathrm{~V}$.

After all the groups were tested, the entire array of magnets was energized to the full operating level, again with no quenches. The entire magnet set was 
tripped at approximately $90 \%$ current because the fringling fleld activated an over-current relay for the solenolds, which automatically fast dumed the entire system. The relay contact was adjusted, and fullcurrent operation was achieved without further Incident.

\section{Coriclusion}

The successful operation of the palr of high-rield axicell collg for MFTF-B, whlch produced a 12-T central rield in a 0.36 th clear bore, demonstraced that large. practical, cryostable magnets can be made with multifllamentary $\mathrm{Nb}_{3} \mathrm{SH}$ using the react-and-wind method. In order to achieve thls operation, however, the strain sensitivity of the conductor sust be understood and respected. Strict quality controls and adherence to procedures based on sound engineering principles tust be implerented.

\section{Acknowledguentg}

The authors wish to acknowledge the contribution of many people, including: R. H. Ealdi, R. E. Tatro, and their entineers at General Jynamios-Convair; the staff of the rurukawa Electric Company; the englneers and techniclans at Lawrence Litrerzore kationa? Laboratory and General Dynafics-Convair who wound and tested the colls; and to V. P. Zuppan for preparing the manuscript. ior'k was perforied under the ausplees of the U.S. Department of Ẽnergy by the Lawrence Liverwore National Laboratory under contract number i-7'405EHG-48.

\section{References}

1. S. T. Wang, T. A. Kozman, C. L. Hanson, D. H. Shiner, J. H. VanSant, and J, P. Zbasntk, "Progresa on Axlcell MIF-B Superconducting Magnet Systers," in Proceedings of loth syciposius on Fusion Engineering, IEEE B3 CH1916-6 NPS, 1324, 1983.

2. T. A. Kozoan, ป. '. Sniger, J. H. VanSant, and J. P. Zbasnik, "Construction and Testing of the
M1rror Fusion Test Facility Magnets", paper PH-1, these proceedings.

3. R. M. Scanlan, J. P. Zoagnlk, R. H. Baldi, J. L. Plckering, Y. Furuto. M. Ikeda, and S. Meguro, "Fabrleation and Evaluation of a Cryostable $\mathrm{Nb}_{3} \mathrm{Sn}$ Superconductor for the Mirror Fuslon Test Fac112ty (MFTF-B), IEEE Mag-21 Number 2, 1087, 1985.

4. STANSOL II - Structural Analysis of Non-Homogeneous Solenolds, Mechanles Research, Inc.. Septerober 1975.

5. J. H. Ekin, "Strain Scaling Law and the Prediction of Uniaxlal and Bending Strain Efrects In Yultirilamentary Superconductors", p. 187 in Ellawentary $\$ 15$ Superconductors, H. Suenaga and A. F. Clark, ed3., Plenum Pres3, New York, 1980.

6. M. J. Cronk, "Solid SAP (CDSAP) User's Manual". General Dynanics Convalr. CASH-CIH-74-0OB. October 1977.

7. R. H. Baldi, R. E. Tatro, K. L. Agarwal, R. E. Bailey, H. F. Baxter. J. E. Eurgeson, I. K. KIm, and A. J. R1tschel, "Developrent of a 12-Tesla Multifilamentary $\mathrm{Nb}_{3} \mathrm{Sn}$ Hagnet for MFTF-B", P. 67 in Advances in Cryogenle Engineering, Vol, 29, R. W. Fast, ed., Platum Press, New York, 1984.

B. J. P. Zbasnik, R. M. Scanlan, D. N. Cornish, R. H. Hoard, R. L. Leber, J.E. Johnston, M. R. Chaplin, A. R. Rosdahl, P. R. Carnahan, D. R. Hathaway, and R. J. Gross, "Construetion and Testing of the $\mathrm{Nb}_{3} \mathrm{Sn}$ Colls for the High-Field Test Facllity", p. 95 in Advances In Cryogenlc EngineerIng, Vol. 29, R. H. Fast, ed.. Plenum Press, New York, 1984.

9. J. H. VanSant and J. P. Zbagnik, "Liquid ilelíum Cooling of the MFTF Superconduct 1ng Magnets", paper LI-8, these proceedings. 